\title{
The Phenomenon of Discipline and Its Conception for Novice Teachers-A Discourse Analysis
}

\author{
Tereza Buchtová, Lucie Kučerová, Štefan Chudý, Pavel Neumeister, \\ Jitka Plischke, Jitka Petrová, Pavla Vyhnálková \\ Faculty of Education, Palacky University in Olomouc, Olomouc, Czech Republic \\ Email: buchtovatereza@seznam.cz, kucerova.lucie-pv@seznam.cz, stefan.chudy@upol.cz, \\ pavel.neumeister@upol.cz, jitka.plischke@upol.cz, jitka.petrova@upol.cz, pavla.vyhnalkova@upol.cz
}

Received 17 March 2015; accepted 16 May 2015; published 19 May 2015

Copyright (C) 2015 by authors and Scientific Research Publishing Inc.

This work is licensed under the Creative Commons Attribution International License (CC BY).

http://creativecommons.org/licenses/by/4.0/

(c) (;) Open Access

\begin{abstract}
This study is oriented on the problems and issues relating to the conception of discipline and methods for novice teachers and presents the results of a research investigation that focuses on the phenomenon of discipline and the creation of a basic discourse about discipline and novice teachers. Discipline is a phenomenon of our time. Maintaining discipline is a routine event for teachers; however, the manner of achieving it is very complex. Every student is an individual in the educational process-and thus, it is also necessary to approach the issue of discipline in the same way. The aim of this study is, to begin with, to identify the possible terminological definitions like discipline, authority, and the professional careers of teachers and novice teachers. Further, the text focuses on the problems and issues of discipline from a variety of different perspectives and concepts; namely, the normative, educational-psychological and methodical perspectives. The whole study, as a consolidated text, based on the research can be divided into three parts; the first, already mentioned above, deals with discipline; the second part specifies the approach and perception of discipline among novice teachers. The last part is devoted to the relationship between teacher and pupil, complemented by Foucault's philosophical perception of the concept of power.
\end{abstract}

\section{Keywords}

Discipline, Novice Teacher, Strategies, Activities, The Concept of Power

\section{Introduction}

There are occupations with shorter or longer histories of their existence, and next to them, some which are related to the development of mankind from its very beginnings. Teaching is just such a vocation. In general, we

How to cite this paper: Buchtová, T., Kučerová, L., Chudý, Š., Neumeister, P., Plischke, J., Petrová, J., \& Vyhnálková, P. (2015). The Phenomenon of Discipline and Its Conception for Novice Teachers-A Discourse Analysis. Creative Education, 6, 711-717. http://dx.doi.org/10.4236/ce.2015.68073 
can say that teaching has existed since the days when teaching someone something became an activity in which some individuals specialized (Průcha, 2002).

Research shows that-for most teachers, discipline represents one of the major problems which often evoke a feeling of helplessness or even impotence. According to research findings, it is clear that behavioural problems that lead to a reduction in the proportion of time devoted to teaching; which significantly damages the learning outcomes. It is thus clear that the condition of the effectiveness of a teacher's job is the skill to ensure and instil discipline and order in their teaching process (Kalhous, Obst, 2009: pp. 386-387).

Kyriacou defines discipline as rules (order), which are essential in order for students to learn effectively. Further, they also say that one needs to be aware that it is important to realize that the assurance and creation of the necessary order in a classroom is much more closely related to more general skills than the actual approach adopted by teachers themselves to undesirable behaviour among pupils. It is a mistake to perceive discipline as something that depends on the approach of teachers to distractions by pupils, regardless of the general form of their teaching abilities (Kyriacou, 2008: p. 95). Another characteristic of discipline is offered by Bendl, who defines it as "conscious adherence to specified standards of conduct.” This is understood to mean to consciously subordinate oneself to the specified standards, and a conscious respect for the rules, regulations or provisions (Bendl, 2004: p. 23).

Research clearly shows that novice teachers especially, have the greatest difficulty with maintaining discipline in a classroom (Kalhous, Obst, 2009: p. 387). The definition of the term "novice teacher"-which would include all these features, does not exist. A potential delimitation of the definition is the temporal aspect. The novice professional teacher phase is characterised as the first to third year of practice (Průcha, 2002). Podlahová (2004: p. 14) defines a novice teacher according to different criteria-from the perspective of mastering their activities and duties. Such a novice teacher is understood as being young, inexperienced, and not yet able to master working techniques and approaches; a teacher who, while having training and competence, lacks teaching experience. Also of interest, are the results of the research investigation set out in the publication The Trainee Teacher by O. Šimoník, where the results show that $75.2 \%$ of respondents have a problem with maintaining discipline in the classroom and 55.3\% have problems with solving disciplinary offenses (Šimoník, 1995). In the Czech Republic, the problem of discipline has drawn the attentions of S. Bendl, M. and P. Rican, Vališová, Chudý; and abroad, J.S. Cangelosi, Ch. Kyriacou, or G. Petty (Kalhous, Obst, 2009: p. 387), for example

One of the most important factors in the field of discipline is the authority of the teacher. A prerequisite, not only for successful pedagogical practise_-but also for maintaining discipline, is precisely this authority (or lack of it) in a teacher. Podlahová divides authority into personal (natural), functional (professional), positional (secondary), formal (ensuing from their position in the organizational chart), and informal (ensuing from the results of their skills, talents, and education) (Podlahová, 2004: p. 89). Further, she goes on to say that the ideal would be if the teacher had informal authority which derived from their control of the subject and from the degree of their pedagogical skills, as well as from having a good relationship with their pupils. This is not so simple however; for example with novice teachers, because their pedagogical competence in maintaining discipline (where the teacher has the authority) is very complicated, and the teacher must work on it (Podlahová, 2004: p. 90).

\section{The Theoretical Basis-Disciplinary Problems}

Among the problematic issues of our times are, undoubtedly, the drop in morals, the lack of discipline, the increasing aggression in society, family crises, the crisis in the roles of father and mother, and the direction given by a school as an institution of education and training (Kartouš, 2012). Thus, we encounter the phenomenon of education throughout life. Discipline is not a separate and isolated phenomenon in educational reality, but however, something which is most frequently manifested in connection with the definition and delimitation of the school environment and concepts like authority, standards, or educational resources. Discipline is perceived from a different point-of-view-depending upon the position of the pupil or teacher. Theoretical insights into the problems and issues of discipline evokes the definition of discipline in the classical and proven ways; however, from the perspective of discourses and their analysis (Discourse Analysis) it is also possible to view discipline from other perspectives. This study will look at the definition of discipline from the content point-of-view; therefore, emphasis is put on the school environment, the social processes and the normative aspect, as well as from the pedagogical-psychological and methodical aspects (Andrysová, Martincová, \& Včelařová, 2014).

\subsection{The Normative Perception of Discipline}

The normative aspect means the precise delimitation and establishment of a clear definition of the elements of 
discipline. It accentuates the aspects of rigour, compliance with norms and standards, and their enforcement. This enforcement takes place in various forms (Hofman, Kyrášek, 1977), and by various means (e.g. Orbis Pictus).

In the course of describing discipline, it is also necessary to mention other aspects, e.g. the historical, psychological and sociological aspects. The priority however, is the aspect of legislation-in the form of legislative regulations. Customs and habits are specific forms of discipline, and discipline is thus perceived as a complex of power-control techniques (Foucault, 2000: p. 218). Another definition is offered by Raskin, who says that discipline is knowledge and the strict preservation of rules, as defined for a specific area (1946: p. 5).

Normative Discourse has the character of norms and standards and discipline is used to achieve the prescribed goals through specific forms of regulation and the control of the individual and thereby helps to create a strong system of discipline, order and standards. These norms and standards protect human society from other individuals and this is the most "protectionist" and noticeable aspect of discipline in the school environment (Jansky, 2004).

The specific legislative norms of a given State (e.g. the Education Act, the Law on Pedagogical Staff, etc.) which regulate the education system, determine compulsory school attendance and its length ${ }^{1}$, determine the areas of education ${ }^{2}$ and regulate the provision of financial subsidies from the public sector to the private sector ${ }^{3}$.

Discourses on normative discipline in the school environment take on an institutional dimension. This so-called "normativity" is presented through the intermediary of a system of norms expressed in the form of school rules (Kartouš, 2011). Knowledge of norms, standards, and order and criminal sanctions also helps to build a relationship between builds a positive teacher—pupil relationship (Škrobák, 2009)—and the pupils themselves. It also helps with socialisation.

\subsection{The Pedagogical-Psychological Concept of Discipline}

The social dimension and the effort to intervene in the educational process through discipline as an educational resource can be expressed for example, in relation to teacher education. We also have educational resources (e.g. physical education—nursing, intellectual education — teaching, moral education—discipline, etc.), depending on the various disciplines and educational activities (Kratochvíl, 1995). The pedagogical dictionary defines discipline as the conscious, accurate performance of the given social role, or set tasks for activities associated with authority (Průcha, Walter, \& Mares, 1998: p. 105). Uher describes the formation of moral values as one of the goals and means of moral education, and says that discipline is voluntary subordination to moral laws (Hungary, 1924). The dimensions and specifications of moral values is another aspect of this concept of discipline. Discipline even determines the character of the teacher-pupil relationship and thus, novice teachers, who do not have much experience do not have precise and validated solutions to indiscipline among students and do not have a built-in higher theoretical framework of the concept of discipline ${ }^{4}$. Thus discipline, apart from the teacherstudent relationship takes on, in this conception, the teacher-I relationship, which addresses the creation of their own concepts presented as strategies for educational activities (e.g. attitudes, opinions and reactions to dealing with situations).

The psychological aspects of discipline can be seen in connection with the biological aspects and in the formation of morality and moral education (Vaněk, 1972). Uher (1924), in his book Discipline Psychologically describes the psychological aspects of discipline in the educational environment. From his text, what is interesting, as stated, is that he focuses on the student as an object of education, whereby the concept of discipline specifies the actual process of education for its actors. Uher further says that an important role in the specification of discipline is also played by social psychology and specifies how social factors and social interactions affect an individual.

The context of our current times predetermines the pedagogical-psychological conception of discipline through the description, detection and prevention of undesirable behaviour in the school environment. Discipline is the aim in the course of the formation of value-orientations, in the form of the application of morality as a means for the educational activities for teachers as well as pupils, educational strategies and even methods for rectifying social dis-integration. Discipline is not just about the negative aspects of education, but is a close

\footnotetext{
${ }^{1}$ Law n. 561/2004 Sb.z. primary, primary, secondary, vocational and other training (Education Act).

${ }^{2}$ In czech languae: The White Paper, general education programs.

${ }^{3}$ Law n. 306/1999 providing subsidies to private schools, pre-school and school facilities, as amended by Act č. 562/2004 Sb.

${ }^{4}$ This view was presented at the lecture doc. Koti at Charles University, April 2012.
} 
interlinkage of the worlds of children and adults. It is precisely these changes in the concepts of childhood and life situations that instead of strengthening the place of discipline in the educational process to a linkage with authority (Grecmanová \& Neumeister, 2004: pp. 242-254).

We can best attain a description of the relationship between discipline and authority by using the definition of authority, which was established by Vališová and team as-institutions, students' self-control and the strengthening of authority in relation to the ideals of the time, peers and peer groups (Vališová, 1999).

Today's school requires a teacher's authority and the maintenance of discipline. At the same time however, discipline should also be informal and should eliminate the excessive superiority of a teacher. So, this has not only to do with formal authority, but also the aspects of the powers and personality of the teacher. As a consequence, there are also issues relating to the management, direction and leadership of classes, etc. These are described more specifically in the methodological approach part (Novotná, 2014).

\subsection{The Methodical Approach to Discipline}

Authority and power, at the educational level, are very closely related with discipline. Mastery of the methodology of educational work helps the teacher to eliminate unwanted sources (e.g. distractions, etc.). The abovementioned standards, rules and educational strategies are the basis of the system of working with discipline. The methodological aspect of discipline is precisely in the mastery of these standards of control, and to modify and observe them. It is necessary to understand this in a wider sense as well. Standards are also a means for the subjugation and regulation of one's behaviour; if this is voluntary, then we talk about the so-called voluntary and conscious mastery of discipline (Bendl, 2001: p. 92). As a consequence, its functions are important for the functionality of discipline. Bendl mentions the following:

- Orientation

- Protection

- Existential

- Social

- Legislative (Bendl, 2001: pp. 93-94)

The methodical concept highlights the aspects of techniques using discipline as a resource for educational activities. This discourse clarifies the relationship between teachers, pupils and discipline and helps teachers to detect and eliminate sources of social pathology; it also moulds the teacher's approach to discipline, shapes attitudes and the acquisition of behaviour patterns and these together create one's own self.

\subsection{Novice Teachers and Discipline}

Each novice teacher is equipped with basic theoretical knowledge that can be applied to maintaining discipline in the classroom. This knowledge and these observations can include strategies for maintaining discipline in the classroom, certain resources - among which we might mention rewards and punishments for students when they are unruly, for example. Furthermore, we can also include certain principles for teachers that many authors mention in their publications. These principles are designed specifically for educators who can be guided by them to establish discipline directly in the class. Finally — but not least of all, a teacher must gain authority over the pupils as well as maintain it. It is widely known that it is precisely this teacher authority that is closely connected with the concept of discipline.

In addition to these strategies, methods, and approaches to discipline, the table below (Table 1) - the discourse analysis results, depicts how the level of perception and approach to discipline in a novice teacher. This table is divided into three levels; namely-low, medium and high levels of perception, by using methods and approaches to discipline for novice teachers (Chudý, 2014).

Thus, the concept of discipline is, for novice teachers, the internal dynamics and structure. From the methodological point-of-view, teachers have a relatively sufficient variety of tools, methods and strategies to ensure that they can lead pupils to discipline. The teacher must find their way themselves through the use of such tools, methods and strategies to ensure that the result is effective and that pupils observe discipline.

\section{The Teacher-Student Relationship and Their Concept of Powers}

On the basis of this definition, we can say that discipline is, for novice teachers, an unavoidable educational tool 
Table 1. The level of perceptions and attitudes of novice teachers to discipline.

\begin{tabular}{|c|c|c|}
\hline A & \multicolumn{2}{|c|}{$\begin{array}{c}\text { Low Level of Use of } \\
\text { (Discipline, Educational Methods, Strategies, etc.) }\end{array}$} \\
\hline \multicolumn{3}{|c|}{ Specific Basic Areas-Teachers } \\
\hline Area & Attitude & Methodology \\
\hline Role of the Teacher & To Their Profession & $\begin{array}{l}\text { Building a Relationship } \\
\text { to Their Profession }\end{array}$ \\
\hline Teacher-Pupil & To Pupils & Classroom Management \\
\hline Concept of Discipline & To Discipline & Discipline, etc. \\
\hline Conception of Educational Styles & To Education & Educational Strategies \\
\hline B & \multicolumn{2}{|c|}{ Middle Level of Use } \\
\hline Cognitive Element & Subjective Theories & \\
\hline Emotional Element & Emotional Expressions & Approach \\
\hline Evaluation Element & Evaluation & \\
\hline $\mathrm{C}$ & \multicolumn{2}{|c|}{ High Level of Use } \\
\hline Everyday Activities & $\diamond$ & Subjective Theories \\
\hline
\end{tabular}

in the socialization process. In the process of forming disciplinary strategies, it often happens that novice teachers conclusions that show the malfunction of "observational” strategies. For this reason, every novice teacher should use the right disciplinary techniques to match the situation in the classroom exactly. The teacher must use disciplinary techniques such that the results are effective, i.e. that students learn to be disciplined and not only create relationships within their collective; but also a positive teacher-pupil relationship.

The content of this chapter is the teacher-pupil relationship, therefore it is appropriate to focus more on the definition of the relationship level by using the concept of power from M. Foucault. It was precisely M. Foucault who looked on power like a relational phenomenon that can be applied in all spheres of interaction (Foucault, 2000).

\section{The Concept of Power According to Foucault}

Foucault uses the concept of power/knowledge for the relationship of power and knowledge. In every society there are power relations. According to Foucault, the exercise of power is "the way of action/behaviour that operates on other people." In connection with the exercise of power, Foucault uses the term "governmentality", which can be translated as governance. According to Foucault, power is closely linked to governance-and not only to the ruling class and a politically structured society. Society is divided into classes, among which there is a certain relationship. This relationship can be understood as dominance. Dominance is another sign of the power relationship that Foucault mentions. Dominance is the relationship between superiority and inferiority. This relationship functions not just between teachers and students for example, but also between institutions, in the management of institutions and in society as a whole. Thus, power is not limited only to the state and the ruling social group, but strengthens the power of one group over a second group, which is excluded through the instrument of the power of the first group that claim this power.

Power/knowledge - a power relationship, is based precisely on the power relationship, characterized as the norm according to Foucault. This standard is scientifically defined. Knowledge and power are externally related to production. New knowledge, competences and knowledge are produced by mechanisms of power (Foucault, 2000).

Foucault also defines pastoral power. This power is a power relationship between the shepherd and his flock. "It is a form of power where the individual controls not only the whole community, but also takes care of the individuals within it” (Foucault, 2000). The aim is to ensure the well-being of individuals, their health etc. So, the shepherd tends his flock. This is a constant concern. Responsibility not only for the whole flock but also for each 
individual is also constant. Of course, this care requires the obedience of the flock, which is seen as a virtue. This power relationship between the shepherd and the flock can also be found in contemporary schools. Thus, in the way in which schools operate today, appear elements and tools just like pastoral power.

Should we want to summarize these power concepts, we can say that the author defines power as a means of achieving certain objectives through the intermediary of the behaviour of others. As indicated above, the aim of a school is thus, to conserve power in this form to raise and educate individuals-pastoral power. Within the framework of this education and training, schools must maintain certain standards, control, and also ensure that the needs of the users of its services are met—not only for students, but also for teachers.

Furthermore, schools delegate power to teachers, who must fulfil the requisite training and educational goals by using elements of power-power/knowledge (Foucault, 2000). As stated above, this concept by Foucault can also be applied to the teacher-student relationship. We can also state that in schools, it is mostly the concept of pastoral power that generally occurs in view of the interaction between teachers and pupils.

\section{Results}

Discipline in the school environment is, in the normative concept as well as in its reflection in pedagogicalpsychological theories, the conscious observance of school regulations and the orders of the teacher. This tends to contribute to increasing pupils' potential and helps the effectiveness of this work (Bendl, 2005).

From the pedagogical point-of-view, we can rank discipline into several categories, depicted above in Table 1, in the Section 2.3 Methodological approach to discipline, which can be defined as:

- Educational objectives;

- Educational activity methods;

- The form of the educational activities;

- The means of educational activities;

- The theories and strategies of educational activities.

Novice teachers can thus use these aforementioned procedures, activities and strategies to achieve effective results-i.e. disciplined pupils. How to get there is up to the novice teachers themselves, because they have enough resources and tools. It is widely known that teachers use these practices and approaches repeatedly. They consider these practices in their teaching practice as granted, as well as catch-points, and—last but not least, as fundamental resources in the pupil socialization process during lessons.

Teachers must know how to act on pupils. Pupils, on the contrary, should know what and under what circumstances, they can expect from teachers. We can say that discipline depends not only on the student and the teacher, but also on the relationship between teacher and student.

The description of this discourse on discipline in terms of power, and power principles by M. Foucault is expressed as a construct of cognitive- the emotional structures of the disciplinary process in which various policies and strategies for education and the socialization of individuals are implemented. Discipline takes place at the pupil-pupil and the pupil-pupil group levels; in the school environment it takes place at the teacher-pupil and teachers-pupils levels. These strategies contain within themselves types of management solutions to social situations among students. In the school environment, this is the pedagogical, educational situation.

Certain advice for teachers exists on how to prevent indiscipline. These tips are also mentioned in the theoretical study. Today however, theory works differently, and practices quite differently. Teachers may be theoretically ready for their pupils and even so it may well happen that in practice; they will not resolve the pupil's indiscipline only by themselves, but perhaps with the school director, or a counsellor or even through educational-psychological counselling. In those cases where a teacher cannot handle an undisciplined pupil themselves, they will therefore need assistance from either the Director or from an educational consultant; an increasingly growing phenomenon nowadays. We cannot say that the fault lies only in teachers, but also in those students who fail to comply with discipline.

\section{Acknowledgements}

IGA_PdF_2015_008 The phenomena of discipline and its changes in the process of constituting the professional beliefs of future teachers.

IGA_PdF_2015_022 The phenomena of relationships between education and thinking in constructivism education. 
Internal grant of PDF UP: From subjective implicit theories of education to teaching knowledge. The process of constitution of a cognitive framework sciences education in the national and international context.

\section{References}

Andrysová, P., Martincová, J., \& Včelařová, H. (2014). Pedagogical Condition at Undergraduate Teacher Praparation. The New Education Review, 4, 152-165.

Bendl, S. (2005). Disciplined Class or Disciplinary Minimum for Teachers. Praha: Triton.

Bendl, S. (2004). How to Prevent Indiscipline, or, Discipline Measures. Praha: ISV.

Bendl, S. (2001). School Discipline. Methods and Strategies. Praha: ISV.

Foucault, M. (2000). Discipline and Punish: The Birth of the Prison Book (p. 216). Praha: Dauphin.

Grecmanová, H., \& Neumeister, P. (2004). Historical Changes in Childhood (A Significant Problem History of Pedagogy). In International Conference on General Education for All. Praha, Pedagogical Museum J. A. Comenius.

Chudý, Š. (2014). Novice Teacher and Management Disciplines in the Context of 2 st. Primary School. Brno: Paido.

Kartouš, B. (2012). What Is the School. MF Dnes, n. 4.9.

Kartouš, B. (2011). Discipline in School: Repression Is Not the Solution, and Part of the [online]. http://www.rodina.cz/clanek8187.htm

Kratochvíl, R. (1925). Reports of Education. Bookstore and Publishing of Žilina, O. Trávníček.

Kyriacou, Ch. (2008). Key Skills Teacher. Praha: Portál.

Novotná, J. (2014). Critical Thinking in Education. London: STS Science Centrue.

Podlahová, L. (2004). First Steps Teachers. Praha: Triton.

Průcha, J. (2002). Teacher: Current Knowledge about the Profession. Praha: Portál.

Průcha, J., Walterová, E., \& Mareš, J. (1998). Pedagogical Dictionary. Praha: Portál, s.r.o.

Škrobák, J. (2009). Foucault’s Concept of Social Power, Disciplinarizácia and Delivery of Public Services. In: Acta Universitatis Facultatis Iuridicae Comenianae (Vol. 27, pp. 403-430). Bratislava: Comenius University in Bratislava.

Uher, J. (1924). Problem discipline. Prague: The Legacy of Comenius.

Vališová, A. (1999). Authority in Education: The Rise, Fall or Slow Return. Praha: Karolinum.

Vaněk, J. (1972). The Biological and Psychological Considerations Education. Praha: SPN. 